\title{
DE LA ESTAMPA
}

Hace algunos años que la estampa ocupa cierta atención en el campo de la investigación para los historiadores del arte. Sin duda alguna, el tan cuestionado Método Iconográfico parece obtener sus resultados. Así, considerando la Iconografía como la ciencia que describe, identifica y clasifica los argumentos visuales, la estampa supone una importante ayuda por cuanto no solamente nos presenta el origen o la difusión de la composición artística, también opera en una mayor comprensión semántica, pues en numerosas ocasiones los textos acompañan el buril.

En un tiempo pretérito quise incorporar a la investigación una bibliografía ajustada (aunque nunca suficiente) para el estudio del arte gráfico. Con este propósito, tienda a tienda, en las calles de Bruselas, Roma o París, formé una pequeña colección de estampas así como la biblioteca del acertado, siempre gozado e intencionadamente sufrido, Instituto Ephialte (un difunto político). Fue sin duda un proyecto personal del que sus frutos poco a poco van emergiendo entre los estudiosos y alumnos. En este sentido comprendí que el grabado no solamente opera en la pintura sino en relieves de retablos, tapices e incluso en la orfebrería. Pero quizá, ya que algunos profesores herederos de esta función han centrado - a manera de conversos bien llegados - en este apartado todo su discurso, sea hora de emprender nuevos y sugerentes propósitos en el campo de la estampa, pues en poco nos quedamos si nos dedicamos exclusivamente a observar las identidades formales de composicion.

Muchos son los modelos a presentar en este sentido. A modo de ejemplo, podemos reparar en el lienzo anónimo que se custodia en el rectorado de nuestra Universidad del País Vasco. Se trata de una pintura del siglo Xvil que nos remite a una de las artes liberales como es la Astronomía (fig. 1). Así reza en la pintura y se define en su iconografía, como lo observamos en la representación de la Geografía mediante la alegoría que porta la esfera y de la Musa de la astrología Urania quien contempla la luna. Bajo la tradicional esfera en la que se asienta la Astronomía aparece Hércules con su piel de león sobre la cabeza y la maza, a su lado el titán Atlas, a quien el héroe del Peloponeso sustituyó en su cometido de sostener la bóveda celeste. Todas estas imagen portan su oportuna inscripción. La figura de Hércules sosteniendo el universo queda traducida en una de las Imágenes de Filostrato $(\mathrm{I}, 20)$ donde leemos culminando el comentario del griego: Ciertamente, Hércules, ahora llevarás sobre tus hombros todos estos seres (se refiere a las constelaciones), pero dentro de muy poco convivirás con ellos en el cielo, bebiendo y abrazando la imagen de Hebe... Para el mitógrafo, el premio a Hércules por su acción se traduce en la inmortalidad celeste y en poseer a Hebe, diosa de la eterna juventud. Es la recompensa que acompaña al hombre que en su esfuerzo, "sostiene el universo", imita a los dioses, de ahí el lema que acompaña a la pintura: Divinas et humanas actiones pando.

El lienzo procede, en su inspiración, de una de las siete estampas que, siguiendo a Primaticcio, fueron editadas por Anton Wierix y que recoge Mauquoy-Hendricks en su conocido catálogo (fig. 2). La pintura se presenta en sentido inverso por lo que se puede pensar que proceda de una copia siguiendo a Martin de Vos que cita Adhemar tomando su referencia de Bruwaert. Toda la serie nos remite a las siete artes liberales que la tradición ajustó siguiendo al norafricano Martianus Capella y a Boecio.

Como podemos apreciar la fuente gráfica queda determinada en la estampa, aspecto que podemos traducir en tapices, es el caso del custodiado en el Banco Hispano Americano (s. XVII. Taller de Jan Leyniers. Bruselas. Cat. p. 109) (fig. 3) que nos remite a las artes liberales, eso sí, con ligeras y notables variantes y que toma su fuente de la estampa firmada por el Monogramista TG siguiendo a Frans Floris que se custodiada en la Colección de El Escorial (Col. 


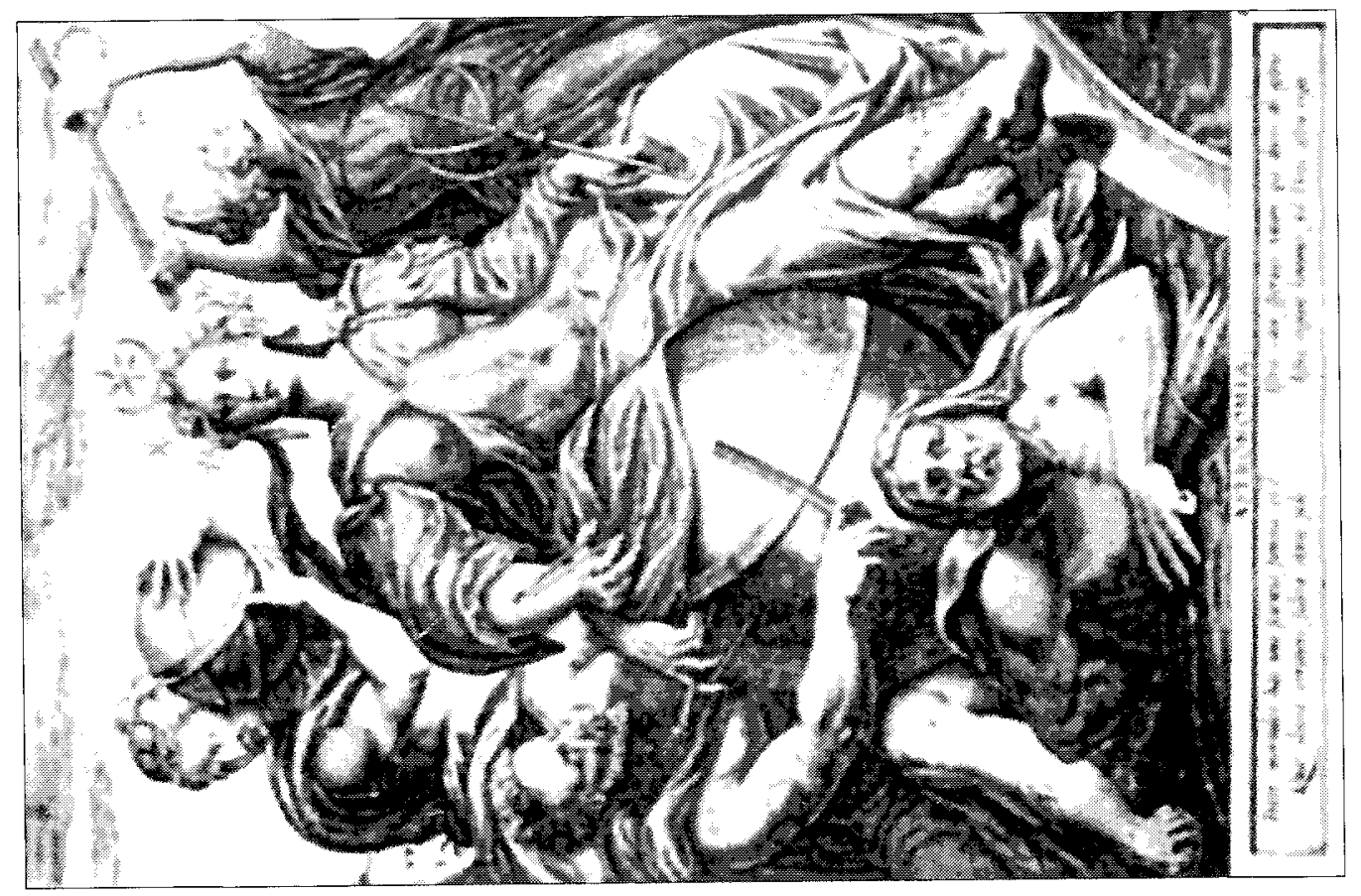

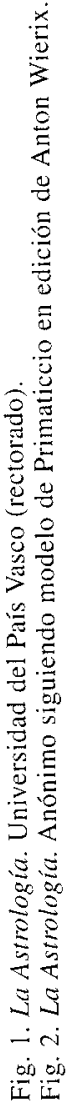

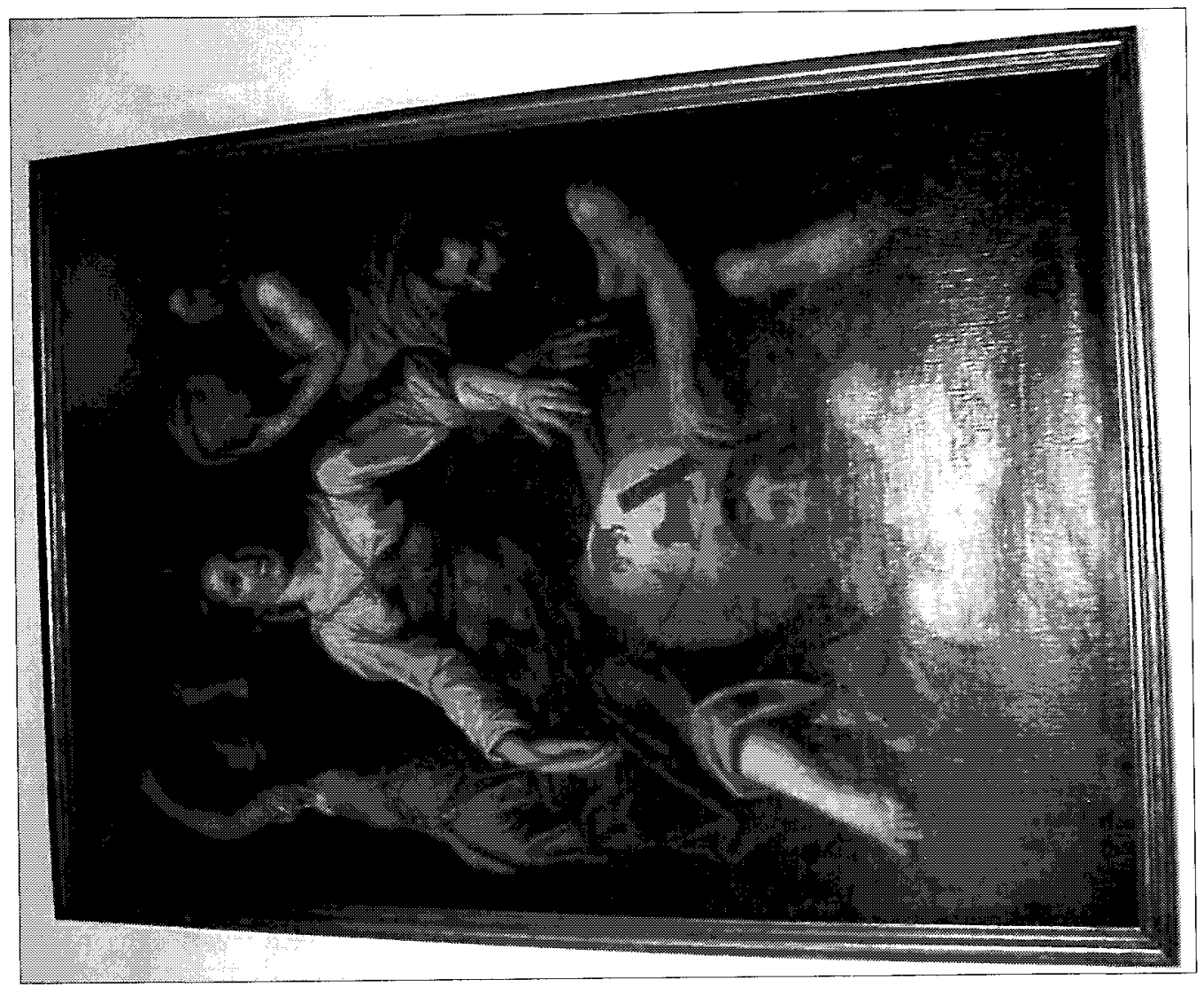




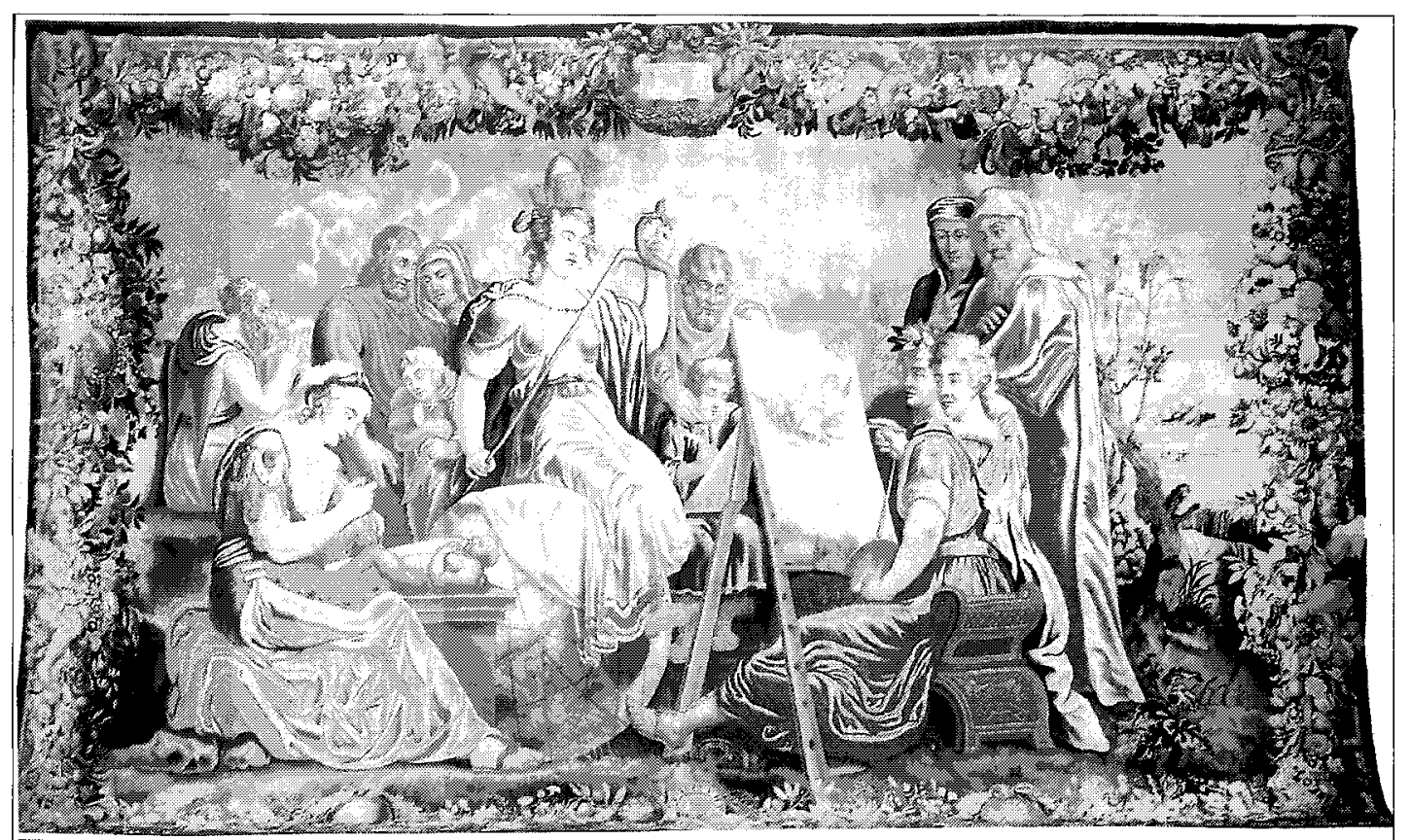

3

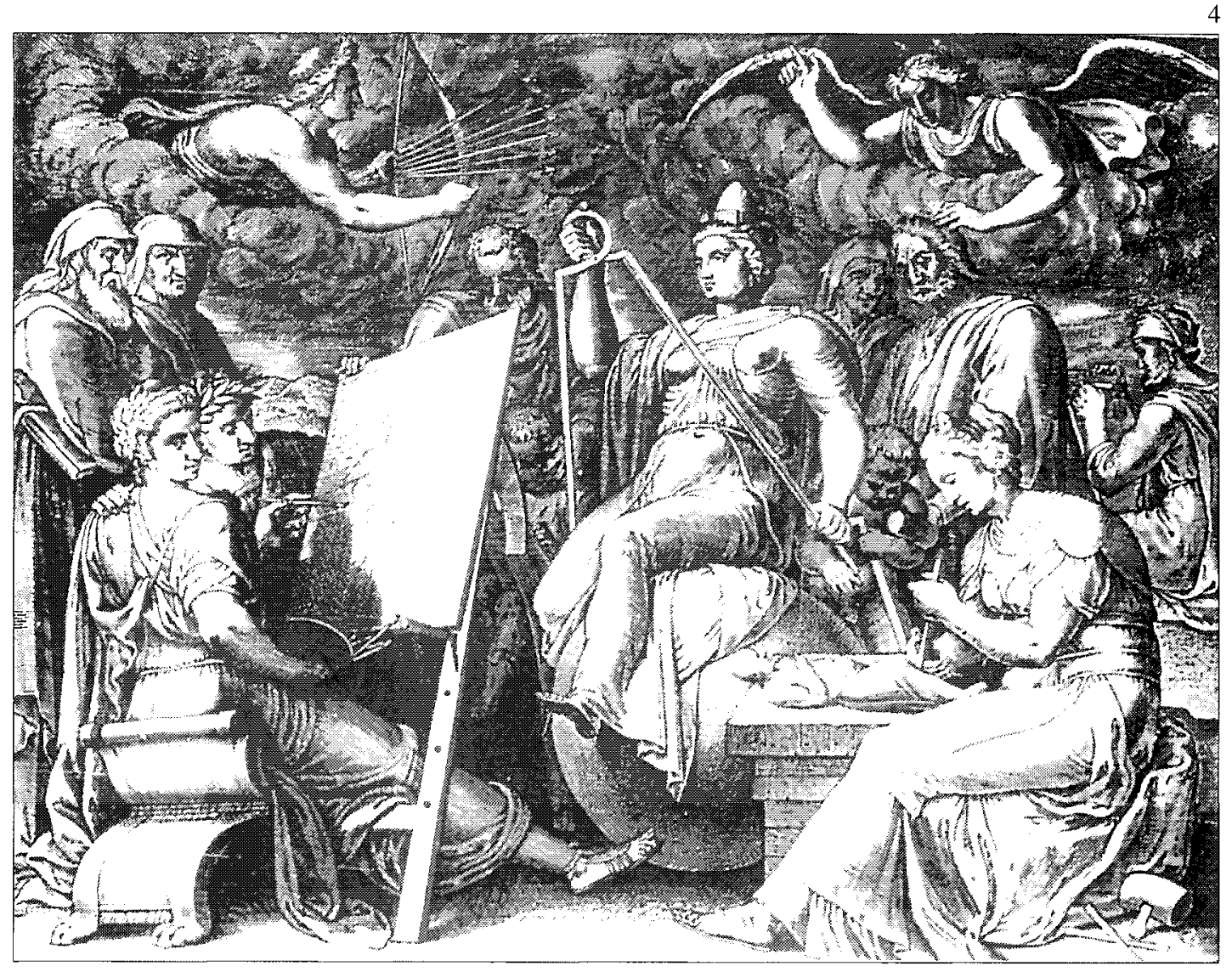

Fig. 3. Alegoria de las Artes. Tapiz. Colección Banco Hispano.

Fig. 4. Alegoría de las Artes (C.E.4780). Monogramista TG siguiendo a Frans Floris. 
Esc. Zárate 4780) (fig. 4). La lámina, difiere del tapiz en que nos muestra la imagen presumiblemente de Apolo lanzando siete flechas (en relación a las siete artes) y en una figura alada que toca sobre la cabeza de quien acompaña a la personificación de la Arquitectura. La zona inferior reproduce el grabado que presentamos y nos muestra las Artes. Estas vienen a romper con la común visión del Trivium y Quadrivium y nos ofrece la incorporación de las artes visuales dentro de las liberales. En este sentido dispone tres artes tradicionales como lo son la Gramática (definida por el libro), la Aritmética (hombre escribiendo números en una tablilla) y la Astrología ya coronada y sobre la esfera como es característico. A estas se añaden las propiamente visuales como la Pintura (con el pincel y el lienzo que registra en el tapiz el rapto de Ganimedes y en la estampa una mujer desnuda), la Escultura (con la talla de un bulto), la Arquitectura (con el querube que porta la maza), la Práctica de las Artes o Diseño, maestra de las artes pictóricas, escultóricas y arquitectónicas, que se define por el hombre maduro que observa al niño dibujando en una tablilla como es su ajustada iconografía y que ya observamos en varias estampas de Goltzius (W.L. Strauss. Retrato del grabador Hans Bol. 316 y Retrato del grabador Johannes Stradanus).

En consecuencia y como podemos apreciar, no es nada del otro mundo proponer modelos gráficos en un tiempo en el que la estampa fue medio recurrente de información visual y artística. Gracias a Dios, esta labor que inicié hace muchos años, se continúa y es muy agradable el escuchar nombres de artistas grabadores que en un pasado reciente eran los grandes olvidados, aunque parezca que es el «gran hallazgo» de estos nuevos y no tan nuevos, pero singulares investigadores de la Historia del Arte.

Volviendo a nuestro coloquio, creo importante insistir en el estudio de la estampa como análisis de los argumentos artísticos, como la creación de un «código visual y semántico» con soporte literario que se hace preciso estudiar y divulgar si de verdad queremos conocer la «perla» de que nos habla Wöllflin: el propósito final de la obra de arte.

Llegados a este punto, la estampa nos ofrece infinidad de imágenes definidas en sus atributos y de concreta y clara lectura que, la «gran enciclopedia iconográfica», como lo fue el Ripa, no nos comenta. Pongamos un ejemplo. La serie de tapices de la Casa Velasco de la que me hice eco en 1985 y que completa en Vitoria hace pocos años hoy, tristemente, se encuentra (o no se encuentra) diseminada en el mundo gracias, eso sí, a la gran preocupación del Gobierno Vasco en estos menesteres - pues tienen asesores - (no obstante algunas de las piezas están en el Parlamento Vasco). Los tapices fueron elaborados a fines del siglo xvi en Flandes y llegaron en la siguiente centuria a Valladolid con Pedro Balmaseda, en 1808 viajaron a Vitoria con Nicasio José de Velasco. Todos los tapices disponen similar orla donde nos ofrecen algunas alegorías acompañadas de su respectiva inscripción, en concreto ocho que podemos considerar brevemente como una construcción visual que, sin duda, toma su precedente e inspiración en la estampa.

Los motivos, salvo la Caridad, referida por la tradicional iconografía de los niños acompañada del conocido y popular lema del Humanismo tal y como estudia Wind Amor vincit omnia, proceden de unas estampas del siglo XvI, de maestro anónimo y que forman parte de los fondos escurialenses. Brevemente las consideramos:

Diligentia (Diligencia) (figs. 5 y 6), se define en la estampa por el cetro alado y el látigo que se observa en la parte inferior. El primero de los elementos ya lo considera Vindel en la divisa del impresor del siglo XVI Juan Rodríguez. El lenguaje parece ser común en este tiempo por cuanto el Látigo lo observamos en Aldegrever (Bartsch VIII.105), en el maestro anónimo (s. M.van Heemskerck. C.E.4860, 4862) y H. Goltzius (W.L.Straus.150). En el tapiz se dispone por el cetro alado tomando su fuente en la composición grabada que se acompaña de la inscripción Diligientiae omnia subiiciuntur (Col.Esc. Ed. Zárate 5095) 

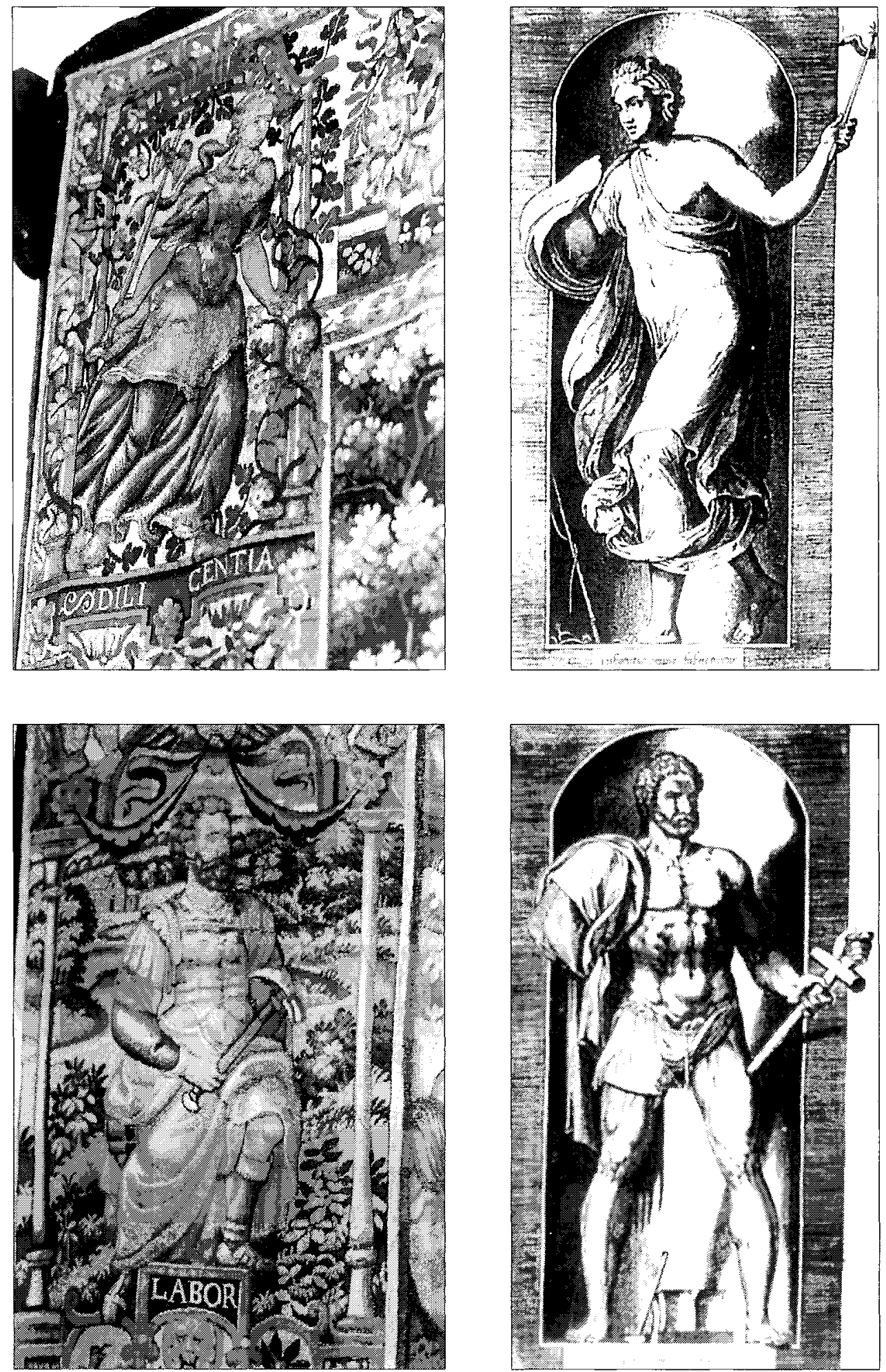

Fig. 5. Diligencia. Tapiz sobre la Guerra de Troya. Orla. (Parlamento Vasco)

Fig. 6. Diligencia (C.E. 5095). Anónimo. Serie sobre las virtudes y las artes liberales y mecánicas

Fig. 7. Trabajo. Tapiz sobre la Guerra de Troya. Orla. (Parlamento Vasco)

Fig. 8. Trabajo (C.E. 5096). Anónimo. Serie sobre las virtudes y las artes liberales y mecánicas. 

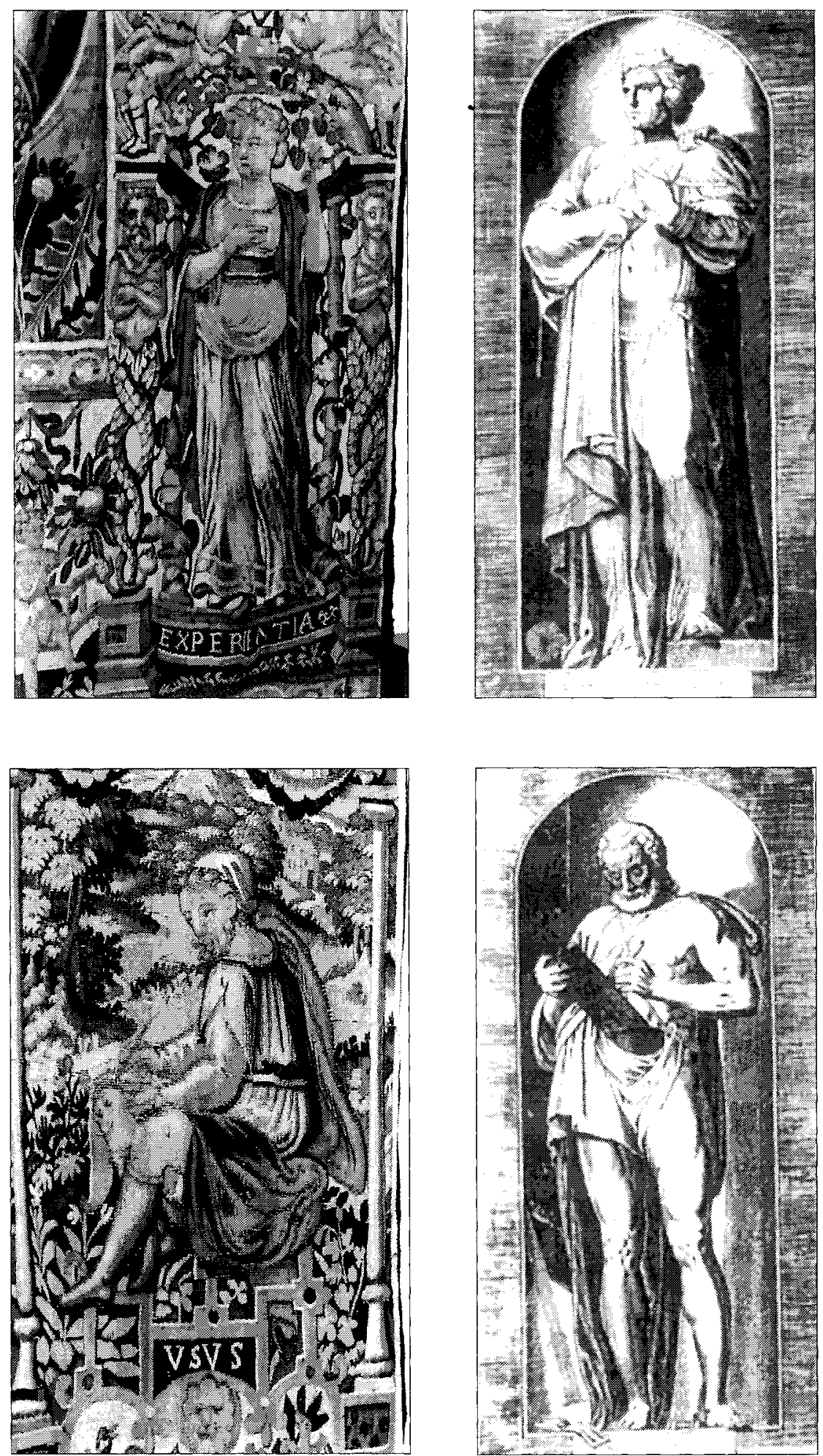

Fig. 9. Experiencia. Tapiz sobre la Guerra de Troya. Orla.. (Parlamento Vasco)

Fig. 10. Experiencia (C.E. 5097). Anónimo. Serie sobre las virtudes y las artes liberales y mecánicas.

Fig. 11. Práctica de las Artes (Diseño). Tapiz sobre la Guerra de Troya. Orla. (Parlamento Vasco)

Fig. 12. Práctica de las Artes (Diseño) (C.E. 5098). Anónimo. Serie sobre las virtudes y las artes liberales y mecánicas. 
Labor (Trabajo) (figs. 7 y 8), se manifiesta en la estampa mediante el martillo del que sobresale una mano y el yunque en la zona inferior. La mano nos remite en los Hieroglyphica de Horapolo al trabajo (H.X.9.II), a la arquitectura o construcción como trabajo elaborado por el hombre y, en este sentido, la observamos como divisa del Impresor Luís Sánchez (s. XVI) y se manifiesta en el tapiz donde vemos los dedos sobresalir en su parte superior. Por lo que respecta al yunque y el martillo, ambos elementos definen el trabajo en la estampa de Goltzius (W.L. Straus.150). La lámina se acompaña del lema Labor omnia vincit (C.E.5096) que ya observamos en los emblemas de Hunius.

Experientia (Experiencia) (figs. 9 y 10), cuya iconografía se define mediante la mano señalando, lo que remite y eștá en clara relación con la imagen del Maestro, de la Elocuencia, así lo apreciamos en estampas de los «pequeños maestros» alemanes como Beham (B.123.164) y Pencz (B.112.355), en el Monogramista B (C.E.4664) y en Pieter van der Heyden (s.P.Bruegel.C.E.2208). La lámina dispone la leyenda Experientia optima magistra (C.E.5097)

Usus (Práctica de las Artes, Dibujo como ciencia esencial en las artes visuales) (fig.11 y 12), quiere definirse mediante el escrito o dibujo en la tabla y un instrumento músico, aspectos que definen la iconografía del Diseño y que con la misma intencionalidad nos proponen las estampas de Goltzius (El arte y la Práctica W.L. Straus.151) y los citados retratos de artistas que recoge W.L. Strauss). El lema que define la estampa reza Non cedit arti usus (C.E.5098).
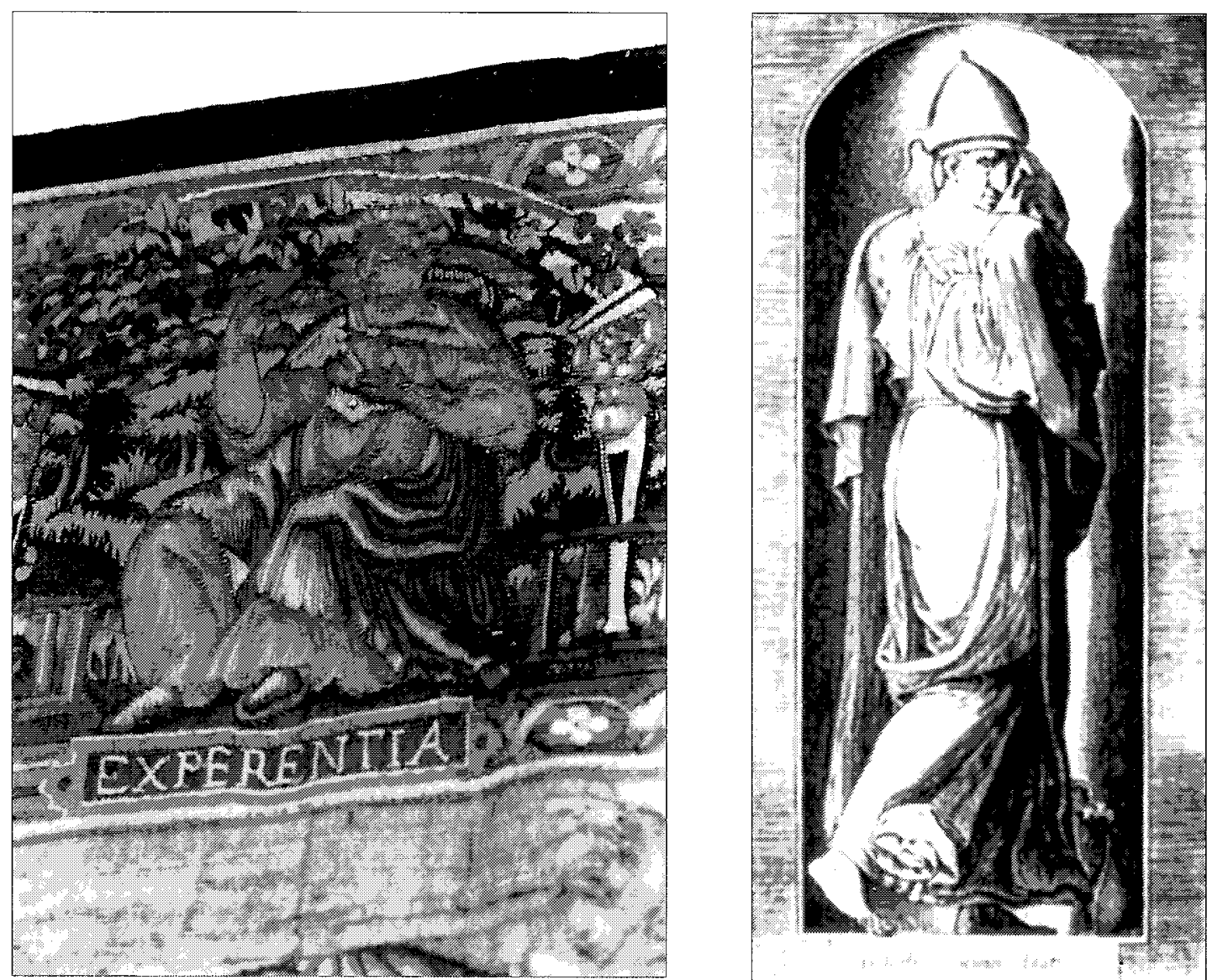

Fig. 13. Ingenir. Tapiz sobre Ia Guerra de Troya. Orla. (Parlamento Vasco)

Fig. 14. Ingenio (C.E. 5099). Anónimo. Scric sobre Ias virtudes y las artes liberales y mecánicas. 

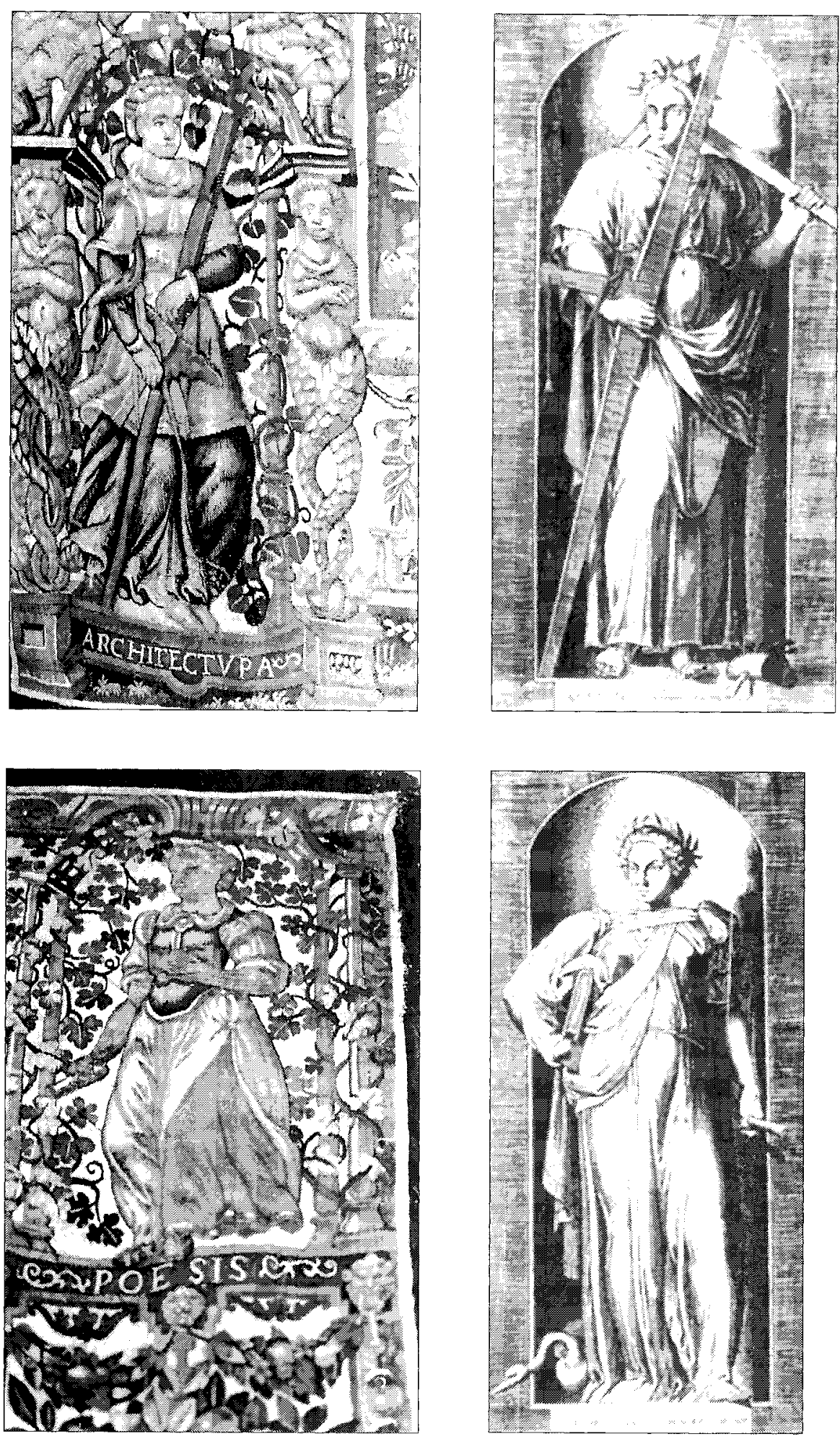

Fig. 15. Arquitectura. Tapiz sobre la Guerra de Troya. Orla. (Parlamento Vasco)

Fig. 16. Arquitectura (C.E. 5100). Anónimo. Serie sobre las virtudes y las artes liberales y mecánicas. Fig. 17. Poesia. Tapiz sobre la Guerra de Troya. Orla. (Parlamento Vasco)

Fig. 18. Poesía (C.E. 5101). Anónimo. Serie sobre las virtudes y las artes liberales y mecánicas. 
Experentia (Ingenio), que apreciamos en la estampa mediante un dedo señalando la cabeza y en tapiz por una figura femenina que observa su mano (figs.13 y 14). La lámina, en su parte inferior, dispone un ave manteniendo el vuelo para poder beber de la estrecha boca de una jarra, aspecto que observamos con el mismo sentido en la divisa de los impresores Francisco y Diego Fernández de Córdoba (s. XVI). En el grabado leemos Industria numen fauet (C.E.5099).

Architectupa (Arquitectura) (figs. 15 y 16) aparece con el compás, la regla, la escuadra y el mazo, elementos comunes a esta disciplina como observamos en tapiz sobre las artes que hemos comentado donde también se dispone el mazo, elemento que se manifiesta en la zona inferior de la estampa. El lema nos dice Architectura urbium ornamentum (C.E.5100).

Poesis (Poesía) (figs. 17 y 18). La estampa, como el tapiz, nos presenta el libro y el pergamino, aquella incorpora en la zona inferior un cisne, este último en referencia a la musa Clio como observamos en las estampas del Tarot en referencia a la Poesía. El lema nos dice Dignum laude virum Musae vetat mori (C.E.5101).

Como podemos apreciar en este sucinto comentario, la estampa propone modelos que las artes en general tomaron como fuente, pero también considera y define atributos que nos permiten conocer e identificar imágenes, definir ideas que se traducen por lo visual. Este es un aspecto importante en el que entiendo debemos detenernos para divulgar imágenes fundamentadas en los soportes literarios que las construyen y en el visual que las difunde. Aquí, aunque dificultoso, encontramos un importante reto que nos lleva a no conformarnos con la simple y mera identidad formal con otras manifestaciones artísticas tenidas por más o menos nobles, más bien a trascender al suceso semántico con que una y otra vez nos asaltan las artes del bien llamado Humanismo.

Jesús María González de Zárate Universidad del País Vasco

\section{LOS PROYECTOS DEL ARQUITECTO FRANCÉS MANSART DE SAGONNE PARA LOS CANALES DEL EBRO Y DEL MANZANARES (1768)}

La llegada del arquitecto francés Jacques Hardouin-Mansart de Sagonne (1711-1778), nieto del gran arquitecto de Luis XIV Jules Hardouin-Mansart, a Madrid durante el verano de 1768 provocó la evolución, poco más o menos voluntaria, según los casos, de unos proyectos de arquitectura o de ingeniería que la administración del rey Carlos III había descuidado desde hacía años. Si esa llegada constituye un episodio totalmente desconocido de la historia de los canales de España por los autores españoles, su análisis permite no obstante medir el interés que tenían unos ingenieros franceses para un país - España - muy descuidado en aquella época y muy atrasado en el plano de las comunicaciones interiores. Sobre todo, es muy instructivo comparar la política de ambos países - Francia y España - ligados por un Pacto de Familia, en cuanto a las concesiones de privilegios para la construcción y la explotación de canales de navegación. Los proyectos de Mansart de Sagonne son emblemáticos de la política resuelta de Carlos III en materia de infraestructuras fluviales favorecida por un tratado de comercio en enero de 1768 . 